
\title{
25 Research Soure \\ River Water Quality and Quantity Determinants in a Developing Country
}

\section{Ibrahim El Khoury}

Notre Dame University Louaize

\section{Caroline Merheb}

Notre Dame University Louaize

Sophia Ghanimeh ( $\sim$ sophia_ghanimeh@hotmail.com )

Notre Dame University Louaize https://orcid.org/0000-0001-5296-2015

\author{
Maya Atieh \\ Notre Dame University Louaize \\ Marianne Saba \\ University of Balamand
}

\section{Research Article}

Keywords: Water Evaluation and Planning model (WEAP), climate change, river flow, river water quality, wastewater discharge

Posted Date: December 2nd, 2021

DOI: https://doi.org/10.21203/rs.3.rs-942390/v1

License: (c) (i) This work is licensed under a Creative Commons Attribution 4.0 International License.

Read Full License 


\section{Abstract}

Developing countries rely to a large extent on international donors to improve water security. Yet, international interventions often end up with low efficiency impacts because of the lack of a priori comprehensive projections. With this in mind, this paper presents a scenario-based methodology to forecast river water quantity and quality in a common multi-stressor situation, that is combined impact of climate change, population growth and wastewater discharge. As an illustrative case, El Kalb River basin, in Lebanon, was simulated under four scenarios up to year 2050, using Water Evaluation and Planning (WEAP) model. The observed trends indicate that mean annual streamflow and flow to groundwater could decrease by around 10 to $23 \%$ each due to climate change, while water demand is expected to increase by 16 to $32 \%$. As to water quality, the maximum BOD of $68 \mathrm{mg} / \mathrm{L}$ (in 2019) can be decreased by introducing wastewater treatment (starting 2021 as planned by national authorities) to $44 \mathrm{mg} / \mathrm{L}$, only to increase again to $63 \mathrm{mg} / \mathrm{L}$ in 2050 due to population growth. Considering climate change, water quality is expected to deteriorate further and the maximum BOD would reach $118 \mathrm{mg} / \mathrm{L}$ and $147 \mathrm{mg} / \mathrm{L}$ in 2050 under RCP 4.5 and RCP 8.5 scenarios, respectively. Even though the planned wastewater treatment facilities would reduce BOD by $34 \%$, it was shown that the river would never meet water standards under any of the proposed scenarios. The approach adopted in this paper is recommended for quantification of the efficiency of river protection plans in developing areas.

\section{Highlights}

- This paper forecasts river water quantity and quality in a multi-stressor situation

- Climate change causes $10-23 \%$ decrease in streamflow and $16-32 \%$ increase in water demand

- Wastewater treatment decreases BOD level, which will increase again to $78-97 \mathrm{mg} / \mathrm{L}$ by 2050

- The scenario approach showed that the river water protection plan is not efficient on the long run

\section{Introduction}

Over the last decades, weather data showed an increasing warming trend at the surface of Earth, and climate models predict further warming and climatic changes throughout the rest of the century (Trenberth 2014; Talib and Randhir 2017). Climate change projections reveal a higher frequency of droughts, accompanied by warmer temperatures that will speed up evaporation from water and land surfaces (Wasimi 2010; Verner et al. 2018). These changes impact the various components of the hydrological cycle, as well as water supply and demand (Alavian 2009; Upadhyaya 2016; Steveninck et al. 2018). On the supply side, water quantity is affected by the changes in runoff, streamflow, groundwater levels and recharge rates. Water quality is also affected by increased saltwater intrusion, due to the rising sea level, and faster biochemical contamination, under higher temperatures. On the demand side, an increased need for water is expected in different sectors, particularly agricultural and residential, due to expected increase in temperature and evapotranspiration, and reduction in precipitation and soil moisture 
(Alavian 2009; Steveninck et al. 2018). These effects are exacerbated by population growth and their impact is pronounced in developing and vulnerable regions of the world.

In Lebanon, a typical developing country of the Middle East, temperature projections show an increase of $1.2^{\circ} \mathrm{C}$ under Representative Concentration Pathway (RCP) 4.5 and $1.7^{\circ} \mathrm{C}$ under RCP 8.5 by 2050 , relative to the baseline period of 1986 to 2005 . Also, precipitation rates are expected to decrease by 4 to $11 \%$ under RCP 4.5 and RCP 8.5, respectively, with drier conditions by the end of the century (MoE et al. 2016). The anticipated climatic changes are presumed to increase the vulnerability of freshwater resources in the country and aggravate the already observed stresses. Lebanon has experienced a rapid decrease in surface water resources in the last four decades (Shaban and Houhou 2015) and a gradual depletion of groundwater, caused by poor water resources management (MoEW and UNDP 2014). In addition, population growth and the influx of the Syrian displaced population have led to a drop of the individual share of annual renewable water resources from more than 1,000 $\mathrm{m}^{3} /$ cap.yr to $770 \mathrm{~m}^{3} /$ cap.yr (Walnycki and Husseiki 2017). The water demand is expected to rise from 1500 MCM in 2020 to $1800 \mathrm{MCM}$ in 2035 , with irrigated agriculture being the largest water-consuming sector in the country (Al-Housseiny 2016).

From a water quality perspective, surface water resources in Lebanon already suffer from high levels of bacteriological, chemical, organic, and inorganic contamination (Haydar et al., 2014). The anticipated changes in weather parameters, associated with climate change, may alter the dilution rate, and thus increase the concentration of pollutants during periods of reduced precipitation and increased evaporation (Sjerps et al. 2017). Also, higher temperatures reduce the dissolved oxygen content in water streams, enhance the dissolution of contaminants, and increase the rate of algal and bacterial growth (Delpla et al. 2009). The above-mentioned facts, combined, have attracted the attention of international donors to support water resources protection projects in Lebanon, with emphasis El Kalb River.

El Kalb River is one of Lebanon's fourteen major rivers and its basin partly overlaps with the catchment of the Jeita Spring, which delivers most (70\%) of the water demand of the capital (Beirut). Thus, the climate induced changes in the hydrological cycle may have detrimental impacts on national water supply (Schuler 2012; Shaban 2021). From a quality perspective, the river is under high physical, chemical, and biological contamination, mostly associates with uncontrolled discharge of liquid and solid wastes from the highly populated surroundings (Schuler 2012; Schuler and Margane 2013). In response, two wastewater treatment plants are planned by the national authorities along El Kalb River (CDR 2018b) to limit the source of pollution.

The Water Evaluation and Planning system (WEAP) is an integrated decision support system that is applied to develop water resources management models at catchment scale (Leong and Lai 2017). WEAP has been repeatedly used to simulate flows, analyze water demand trends, and project the impacts of various natural and anthropogenic factors on water quantity and quality in different regions of the world (Amin et al. 2018; Kumar et al. 2019; Pallavi et al. 2021; Majedi et al. 2021). Reported WEAP-based studies in Lebanon include a hydrological balance assessment of the Jeita Spring catchment (which 
includes El Kalb River). Yet, until this date, there exist no projection of streamflow and final water quality of El Kalb River, under the anticipated climatic changes, that takes into consideration the effectiveness of environmental protection actions, such as the construction of new wastewater treatment plants.

The combined impact of climate change, population growth and wastewater discharge (or interrupted discharge) is specific to (and common for) rivers in developing countries. It is in line with attempts from international organizations to assist national authorities to better plan the exploitation of major rivers and neighboring watersheds. Yet, this combination has been seldom approached from a scenario perspective, with a comprehensive analysis of both quantity and quality projections. Therefore, this study applies WEAP to the case of El Kalb River, accounting for population growth, climate change and/or wastewater treatment, aiming to develop a systematic approach to generate simple and easy to understand, yet sufficient, data for informed decision making.

\section{Materials And Methods}

\subsection{Study site and measurement locations}

El Kalb River, with a length of $31 \mathrm{~km}$, is located north of Beirut in Mount Lebanon Governorate. The river originates from the highlands of the Kesrouane area and is fed by interflow and runoff that occur shortly after events of rainfall and snowmelt. It runs from the Jeita Grotto to the Mediterranean Sea. The river catchment, having a total area of about $249 \mathrm{~km}^{2}$, consists of four sub catchments joining to form the main branch of the river (Doummar and Aoun 2018).

The watershed of El Kalb River and the boundaries of the sub catchments within the basin were delineated using ArcMap 10.4. Fig. 1 shows the watershed surface, the sub catchments areas, the stream gauge station (Sea Mouth), and the BOD sampling sites (S1 to S4).

\subsection{Flow and BOD measurements}

Flow data for the years 1993 to 2017 have been obtained from a stream gauge station, situated downstream of the river course (Fig. 1). The mean annual flow is $5.5 \mathrm{~m}^{3} / \mathrm{s}$, with the highest mean monthly flow occurring in January $\left(14.3 \mathrm{~m}^{3} / \mathrm{s}\right)$ and the lowest in August $\left(0.3 \mathrm{~m}^{3} / \mathrm{s}\right)$ during flow recession periods.

Water quality was assessed through a sampling campaign during the wet and dry seasons of year 2019 . The samples were tested for biochemical oxygen demand (BOD) - considered indicative of wastewater contamination. Sampling points (S1 to S4) are shown on Fig. 1. BOD values varied from $32.5 \mathrm{mg} / \mathrm{L}$ to $58.3 \mathrm{mg} / \mathrm{L}$ in January 2019, and $42.1 \mathrm{mg} / \mathrm{L}$ to $69.7 \mathrm{mg} / \mathrm{L}$ in August 2019 (see Table S1 of the supporting information for water temperature and BOD values at each sampling location).

2.3 Land use, soil, and hydrogeology 
The land use (Fig. 2a) and soil cover maps (Fig. 2b) of the study area were generated in ArcMap 10.4 using data extracts from the "OpenStreetMap" project (GEOFABRIK downloads 2018). Eight land use classes were identified (Fig. 2a) with be non-irrigated (rainfed) lands being more abundant than irrigated (agricultural) areas (Table S2 of the supporting information). Groundwater basins in the study catchment were also delineated in ArcMap with reference to the United Nations Development Programme (UNDP)'s map of groundwater basins in Lebanon (MoEW and UNDP 2014). The main aquifers, identified in Fig. 2c, are the High Central Mount Lebanon Cretaceous Basin, the Kesrouane Jurassic Basin, the Metn Shouf Cretaceous Sandstone Basin, and the Aptian-Albian Basin. Areas above the Jurassic unit are expected to have an infiltration rate of 50 to $60 \%$ of effective precipitation, while those above the High Central Mount Lebanon cretaceous unit are expected to have an infiltration rate of about $80 \%$ of effective precipitation. The remaining units are semi-aquifers which may allow minor infiltration and storage of groundwater (Schuler 2012; Schuler and Margane 2013; MoEW and UNDP 2014). Transmissivity values of the different geologic units were estimated between 0.01 to $1 \mathrm{~m}^{2} / \mathrm{s}$ for the Jurassic and the Cretaceous basins, and between 0.00001 to $0.0001 \mathrm{~m}^{2} / \mathrm{s}$ for the Cretaceous Sandstone basin. Moreover, the potential thickness of each aquifer was determined as follows: 200 to $600 \mathrm{~m}$ for the Cretaceous Basin, 10 to $300 \mathrm{~m}$ for the Cretaceous Sandstone Basin, 1000 to $1500 \mathrm{~m}$ for the Jurassic Basin, and $50 \mathrm{~m}$ for the unproductive Aptian-Albian Basin (MoEW and UNDP 2014; Badoux et al. 2014).

\subsubsection{Population and water demand}

Kesrouane and El Metn are the two districts that partly overlap with El Kalb River basin, with population densities of $544 \mathrm{p} / \mathrm{km}^{2}$ and $1991 \mathrm{p} / \mathrm{km}^{2}$, respectively (Lebanese Republic 2018) and 1\% annual population growth rate (CDR 2018a). Fifteen domestic water demand sites were defined in Fig. 2d, considering 220 liters per capita per day (Icd) average unit demand rate (El Amine 2016).

To determine actual evapotranspiration and irrigation water requirements of different crops in WEAP, the crop coefficient, required for each land class type (Sieber and Purkey 2015; SEI 2016) was adopted from the "National Guidelines for Greenhouse Rainwater Harvesting Systems in the Agricultural Sector of Lebanon" (MoE and UNDP 2016). Particularly, monthly values of the crop factor for all irrigated crops incorporated in the model were developed (Table S3 of the supporting information), with the assistance of local farmers and following FAO guidelines (FAO 2020). An irrigation efficiency of $60 \%$ was assumed, as suggested by previous studies in El Kalb River basin (Schuler 2012).

\subsubsection{Weather data}

In general, the climate is seasonal and is classified as Mediterranean, with the highest precipitation between November and March, and relatively little to no precipitation during summer. The mean precipitation is about $450 \mathrm{~mm}$ per year, and the average temperature is $14.6^{\circ} \mathrm{C}$. Average monthly values of weather parameters (precipitation, air temperature, wind speed, relative humidity, cloudiness fraction and calculated solar radiation) were obtained from the station of Qartaba (shown on Fig. 1) for the years 2012 to 2017 (World Weather Online 2020). 


\subsubsection{Water storage and wastewater treatment plants}

To date, the only existing reservoir for surface water storage in the vicinity of El Kalb River basin is Chabrouh Dam. It is designed to deliver $60,000 \mathrm{~m}^{3} /$ day to Kesrouane district and leaks up to 200 liters/second due to the karstic nature of the geological formations in the area (MoE et al. 2011; ECODIT LIBAN 2015). The monthly storage and discharge rates of the dam for the year 2010/2011 were used in this study (Schuler 2012). In addition, two wastewater treatment plants were planned to start operation in 2021 - at a capacity of $6000 \mathrm{~m}^{3} /$ day (to serve 35,000 to 40,000 people) (UNDP 2013). Secondary treatment, with 85\% BOD removal efficiency, was assumed for both plants (Salman et al. 2016).

\subsubsection{Current wastewater management}

The daily generation of domestic wastewater was assumed to be $165 \mathrm{lcd}$ (Karam et al. 2013) and a corresponding average water supply rate of $220 \mathrm{lcd}$. A BOD load of $31 \mathrm{~kg} / \mathrm{capita} / \mathrm{year}$ was assumed calculated based on domestic wastewater generation figures across Beirut and Mount Lebanon (58603 $\mathrm{Mg}$ of $\mathrm{BOD}_{5}$ /year (MoE et al. 2014) for a population of 1,887,122 residents (CDR 2018a). It is assumed that the untreated wastewater is equally discharged into: (1) El Kalb River and other streams through direct discharge, and (2) underground hydrogeological units via leaking cesspits (Schuler 2012).

\subsubsection{WEAP model development}

Upon establishing the boundaries of the study area, the watershed components were defined (river tributaries and mainstem, subcatchments, domestic demand sites, water supply sources), as well as the planned wastewater treatment plants (Hrajel and Jeita) and the stream gauge station (Sea Mouth). Hydrological modelling was performed using the Soil Moisture Method in WEAP. This method incorporates the impacts of land use and soil types on water availability and allows the characterization of surface runoff, evapotranspiration (including irrigation), and subsurface flows (Sieber and Purkey 2015; SEl 2016). Flow to groundwater was simulated by connecting each catchment node to a groundwater node through an infiltration link.

The generated model, illustrated in Fig. 3, accounts for surface water-groundwater interaction by simulating groundwater discharge to the stream, but does not consider interflow and external inflows and outflows from and to surrounding catchments and aquifers.

The oxygen balance in the river was simulated using the water quality module in WEAP. It is based on the Streeter-Phelps model which accounts for consumption of organic matter (BOD exertion) and reaeration across the air-water interface. The model incorporates water temperature, depth and velocity, and the rates of reactions, decomposition and re-aeration (Kumar et al. 2017). The water quality model factors and constants were adopted from the literature (Sieber and Purkey 2015).

2.4 Model calibration and validation 
Streamflow values at Sea Mouth, for years 2012 to 2015, were used for calibration of the hydrological model; flow data for the years 2016 and 2017 were used for validation. The parameters needed for the Soil Moisture Method (soil water capacity, root zone conductivity, runoff resistance factor and preferred flow direction), as well as the discharge rate of groundwater to the river, were adopted from the literature (Sieber and Purkey 2015; Quoc 2016; SEI 2016; Amin et al. 2018). The calibration of the water quality model was done manually, by adjusting the river geometric characteristics (stage and water width) and BOD generation rate to fit the observed values (Kumar et al. 2017; Kumar et al. 2019). The Nash Sutcliffe efficiency index (NSE), the percent bias (PBIAS), and the coefficient of determination $\left(R^{2}\right)$ were used to evaluate the model performance (Quoc 2016; Leong and Lai 2017; Rauf and Ghumman 2018; Yaykiran et al. 2019).

\section{Simulated scenarios}

The scenarios simulated in this analysis span from year 2012 (baseline year) to year 2050, and consider three factors: population growth, wastewater treatment and discharge, and climate change. The businessas-usual condition was represented by a reference scenario (Scenario 1), with an annual population growth rate of $1 \%$, while climatic changes and the implementation of the wastewater treatment plants were modeled as scenarios that represent future deviations from the current conditions. Climate change projections are based on two Representative Concentration Pathways (RCPs) defined by the Intergovernmental Panel on Climate Change: RCP 4.5 and RCP 8.5. By midcentury, a temperature increase of $1.2^{\circ} \mathrm{C}$ and $1.7^{\circ} \mathrm{C}$, with a decrease in precipitation of $4 \%$ and $11 \%$, are expected under RCP 4.5 and RCP 8.5 , respectively (MoE et al. 2016).

Scenario 1: Reference - The purpose of Scenario 1 is to quantify current water quantity parameters of the catchment, and the impact of prolonged wastewater discharge on water quality of the river, considering population growth only.

Scenario 2: 2-A (RCP 4.5) and 2-B (RCP 8.5) - Scenario 2 analyzes the effects of climate change on the catchment hydrological components and river water quality. The yearly changes in temperature and precipitation were assumed to be linear, at the following respective rates: $+0.4^{\circ} \mathrm{C}$ per decade and $-1.33 \%$ per decade under Scenario 2-A (RCP 4.5), and $+0.56^{\circ} \mathrm{C}$ per decade and $-3.66 \%$ per decade under Scenario 2-B (RCP 8.5). Under this scenario, the wastewater treatment plants remain non-operational.

Scenario 3 - Compared to Scenario 1, Scenario 3 analyzes the impact of the proposed wastewater treatment plants on the river water quality - considering that operation starts on year 2021. The discharge of untreated wastewater into the river is stopped. Instead, an outflow of wastewater from generation sites to the treatment plants and an inflow of treated wastewater to the river were introduced.

Scenario 4: 4-A (RCP 4.5) and 4-B (RCP 8.5) - Scenario 4 analyzes the combined effects of wastewater treatment and climate change on the river water quality. Consequently, the same climatic changes in Scenario 2 were applied and wastewater treatment was incorporated following the same approach of Scenario 3. 


\section{Results And Discussion}

\subsection{Model performance}

\subsubsection{River flow model}

Figure 4 illustrates the observed and simulated monthly streamflow results for the calibration and validation periods. The calculated NSE values range from 0.80 to 0.90 for the calibration period and 0.81 to 0.91 for the validation period (average NSE value is 0.85 ). The $R^{2}$ values vary from 0.82 to 0.92 for the calibration period and 0.85 to 0.92 for the validation period (average $R^{2}$ value is 0.88 ). These results indicate adequate performance. The negative PBIAS values, ranging from $-1.1 \%$ to $-20.9 \%$ (average PBIAS value is $-11.1 \%$ ), suggest that the model tends to underestimate streamflow (see Tables S4 to S9 of the supporting information).

\subsubsection{Water quality model}

Fig. 5 illustrates the observed and simulated BOD values for the months of January and August 2019. Adequate performance was observed for all statistical indicators, with an average NSE value of 0.90 , an average $R^{2}$ value of 0.95 , and an average PBIAS value of $-2.1 \%$ (see Table $S 10$ of the supporting information).

\subsection{Water quantity}

\subsubsection{Water budget components}

The impact of climate change was analyzed by comparing the model outputs at catchment level for Scenarios 1 and 2 (Table S11 of the supporting information). Under Scenario 1, mean annual precipitation is estimated at $160 \mathrm{MCM}$. Losses to evapotranspiration amount to at $37 \mathrm{MCM}$ and represent approximately $23 \%$ of the water budget. Surface runoff, projected at $47 \mathrm{MCM}$, corresponds to approximately $29 \%$ of the available water resources, whereas flow to groundwater represents the largest component of the water balance at approximately $76 \mathrm{MCM}(47 \%)$. This distribution of available water resources in El Kalb River basin is closely similar to that established by previous studies for the Jeita Spring catchment (years 2010 to 2012), where evapotranspiration, surface runoff, and flow to groundwater contributed to $20 \%, 27 \%$, and $52 \%$ of the available water resources, respectively (Schuler 2012). It is also similar to figures determined at the national level (2008 to 2012): $20 \%$ for evapotranspiration losses, $27 \%$ for surface runoff, and $53 \%$ for groundwater inflow (MoEW \& UNDP, 2014). Also, the simulated flow values confirm the findings of Shaban (2019) that a great portion (> 55\%) of precipitation is lost to evapotranspiration or is rapidly absorbed into the subsurface, feeding deep karstic aquifers.

Due to climate change, the mean annual precipitation could decrease by 6 to $17 \mathrm{MCM}$ under Scenario 2-A (RCP 4.5) and Scenario 2-B (RCP 8.5), respectively. With the anticipated rise in temperature, mean annual evapotranspiration is expected to increase by $6 \mathrm{MCM}(+17 \%)$ under RCP 4.5 and $10 \mathrm{MCM}(+7 \%)$ under 
RCP 8.5. Moreover, mean annual surface runoff is expected to decrease by $5 \mathrm{MCM}(-10 \%)$ under RCP 4.5 and $10 \mathrm{MCM}(-21 \%)$ under RCP 8.5. This outcome concurs with observations in other main river basins in Lebanon, reporting a runoff decrease of $18 \%$ in the Upper Litani River basin and $22 \%$ in the Lower Litani River basin for a $2^{\circ} \mathrm{C}$ temperature increase and a $10 \%$ precipitation decrease (Ramadan et al. 2013). Less flow to groundwater is also predicted, with a decrease of 8 MCM (-10\%) under RCP 4.5 and 17 MCM $(-23 \%)$ under RCP 8.5 .

\subsubsection{Streamflow}

The mean annual streamflow of El Kalb River is estimated at about 91 MCM for the years 2012 to 2050 (Table S11 of the supporting information). With climate change, the streamflow is expected to decrease by $9 \mathrm{MCM}(-10 \%)$, equivalent to $0.3 \mathrm{~m}^{3} / \mathrm{s}$, under Scenario 2-A (RCP 4.5), and $21 \mathrm{MCM}(-23 \%)$, corresponding to $0.6 \mathrm{~m}^{3} / \mathrm{s}$, under Scenario 2-B (RCP 8.5). This result suggests a significant flow recession trend similar to that observed in the Upper and Lower Litani basins, where streamflow reductions of 0.8 and $0.7 \mathrm{~m}^{3} / \mathrm{s}$ were anticipated due to climate change (Ramadan et al. 2012).

\subsubsection{Domestic and irrigation water demand}

For an annual population growth rate of $1 \%$, domestic water demand increases from 14 MCM in 2012 to 20 MCM in 2050, with a mean annual value of 17 MCM, assuming that the per capita domestic water consumption of 220 lcd does not vary with climate change. Mean annual water demand for agricultural use is estimated at $23 \mathrm{MCM}$ under Scenario 1, which represents nearly $58 \%$ of the total water demand. Since no major industries were identified in the studied catchment, these values are slightly different than official national figures (61\% for agriculture, $30 \%$ for domestic use, and $9 \%$ for industrial use) (MoE et al., 2014). With the increase in evapotranspiration due to climate change, water demand for irrigation is expected to rise by about 4 MCM under Scenario 2-A (RCP 4.5) and 7 MCM under Scenario 2-B (RCP 8.5). Consequently, the mean annual water demand will increase to $44 \mathrm{MCM}(+16 \%)$ under RCP 4.5 and 47 MCM (+32\%) under RCP 8.5 , accompanied by a 10 to $23 \%$ decrease in water supply.

\subsection{Water quality}

\subsubsection{Impact of wastewater treatment}

The impact of wastewater treatment on the river water quality was examined by comparing the maximum annual BOD concentrations of Scenarios 1 and 3 (Fig. 6a) at Sea Mouth point. Under Scenario 1, the maximum annual BOD concentration in El Kalb River is estimated at about $68 \mathrm{mg} / \mathrm{L}$ in 2019. This value reflects an alarming level of pollution, as it exceeds the allowable national standard and the WHO threshold of $25 \mathrm{mg} / \mathrm{L}$ for wastewater discharge into surface water and the sea (Karam et al. 2013; Haydar et al. 2014). With a population growth rate of $1 \%$ and an additional volume of domestic wastewater discharged into the river, the maximum annual BOD concentration increases to $94 \mathrm{mg} / \mathrm{L}(+38 \%)$ in 2050 under Scenario 1. Operating the planned wastewater treatment facilities reduces the maximum annual BOD concentration to $44 \mathrm{mg} / \mathrm{L}(-33 \%)$ in 2021 only for the BOD concentration to re-increase progressively 
to $63 \mathrm{mg} / \mathrm{L}$ in 2050. The outcome of Scenario 3 reveals that the treatment facilities under preparation are expected to fall short in achieving adequate water quality at the downstream reaches of the river. Water deterioration due to population growth, and the discharge of wastewater from upstream sites that are not served by the treatment plants, outweigh the expected reduction of pollutants discharge.

\subsubsection{Impact of climate change}

The impact of climate change on the river water quality was analyzed by comparing the model outputs of Scenario 1 to Scenarios 2 and 4 (Fig. 6b). Climate change aggravates the deterioration of water quality, leading to a maximum annual BOD concentration of $118 \mathrm{mg} / \mathrm{L}(+25 \%)$ in 2050 under RCP 4.5. This value becomes as high as $147 \mathrm{mg} / \mathrm{L}(+56 \%)$ under RCP 8.5. Introducing wastewater treatment reduces the maximum annual BOD concentration to 78 and $97 \mathrm{mg} / \mathrm{L}$ in 2050 under RCP 4.5 and RCP 8.5, respectively. Accordingly, the planned wastewater treatment facilities would reduce the BOD concentration by about $34 \%$. Yet, the river water quality would not meet national or international standards. The scenario approach adopted in this study may be replicated to quantitively forecast the efficiency of national river water protection plans in developing regions of the world.

\section{Conclusions}

In this study, El Kalb River basin was modeled in WEAP in order to assess the future impacts of population growth, climate change, and wastewater treatment on the catchment water balance and river water quality, for the period between 2012 and 2050. Under climate change, mean annual surface runoff and flow to groundwater were projected to decrease by 10 to $21 \%$ and 10 to $23 \%$, respectively. Mean annual evapotranspiration could rise by 17 to $27 \%$, while mean annual streamflow could decrease by 10 to $23 \%$, corresponding to a flow recession of 0.3 to $0.6 \mathrm{~m}^{3} / \mathrm{s}$. Moreover, mean annual water demand is expected to increase by 16 to $32 \%$.

Water quality simulation results showed that the maximum annual BOD concentration of $68 \mathrm{mg} / \mathrm{L}$ (in 2019) may be decreased to $44 \mathrm{mg} / \mathrm{L}$ by 2021 , upon operation of two wastewater treatment facilities which remains above the national threshold. Afterwards, the maximum annual BOD starts to increase again to reach $62 \mathrm{mg} / \mathrm{L}$ by 2050 . Adding the effect of climate change, further deterioration of the river water quality is expected, and the maximum annual BOD would surge to $78 \mathrm{mg} / \mathrm{L}$ to $97 \mathrm{mg} / \mathrm{L}$ in 2050 , under RCPs 4.5 and 8.5. In conclusion, the scenario approach adopted in this study shows that the river water protection plan is not efficient on the long run.

\section{Declarations}

\section{Acknowledgments}

The authors acknowledge the Litani River Authority (LRA) for providing streamflow data of El Kalb River.

\section{Ethical Approval}


Not applicable.

\section{Consent to Participate}

Not applicable.

\section{Consent to Publish}

Not applicable.

\section{Author Contributions}

I.K. and C.M. conducted the modeling work and developed the preliminary analysis and initial draft of the manuscript, under the guidance and supervision of and S.G. and M.A. who both conceptualized the study and finalized the manuscript. M.S. provided the BOD monitoring data and acted as the consultant for water quality anlysis.

\section{Funding}

No external funding was received for conducting this study.

\section{Competing Interests}

The authors declare no conflict of interest.

\section{Availability of Data and Materials}

Authors can confirm that all relevant data are included in the article and its supplementary information files. ArcMap 10.4 and WEAP 19.2.0.20 were used for this study

\section{References}

1. Alavian V, Qaddumi HM, Dickson E, Diez SM, Danilenko, AV, Hirji, RF et al (2009) Water and climate change: understanding the risks and making climate-smart investment decisions (English) (Vol. 1, Report No. 52911). World Bank Group, Washington, D.C.

2. Al-Housseiny RS (2016) National guideline for rainwater harvesting systems. United Nations Development Programme, Beirut, Lebanon

3. Amin A, Iqbal J, Asghar A, Ribbe, L (2018) Analysis of current and future water demands in the upper Indus basin under IPPC climate and socio-economic scenarios using a hydro-economic WEAP model. Water 10(5):573. https://doi.org/10.3390/w10050537

4. Badoux V, Ollinger D, Baujard C, Mége T et al (2014) The national geothermal resource assessment of Lebanon: country energy efficiency and renewable energy demonstration project on the recovery of Lebanon. United Nations Development Programme, Beirut, Lebanon 
5. CDR (2018a) Lebanon - Roads and Employment Project: Environmental Assessment: Environmental and Social Management Framework (English) (Vol 1, Report No. SFG4765). World Bank Group, Washington, D.C.

6. CDR (2018b) Progress Report. Council for Development and Reconstruction, Beirut, Lebanon.

7. Delpla I, Jung AV, Baures E, Clement M, Thomas $O$ (2009) Impacts of climate change on surface water quality in relation to drinking water production. Environ Int 35(8):1225-1233. https://doi.org/10.1016/j.envint.2009.07.001

8. Doummar J, Aoun M (2018) Occurrence of selected domestic and hospital emerging micropollutants on a rural surface water basin linked to a groundwater karst catchment. Environ Earth Sci 77:351. https://doi.org/10.1007/s12665-018-7536-x

9. ECODIT LIBAN (2015) Strategic environmental assessment for the new water sector strategy for Lebanon: Final SEA Report, Deliverable 4 (Regional Governance and Knowledge Generation Project Plan Bleu 2013-012). ECODIT, Beirut, Lebanon

10. El Amine Y, (2016) Lebanon Water Forum Rethinking Water Service Provision in Lebanon. AUB ScholarWorks https://scholarworks.aub.edu.lb/handle/10938/21134 Accessed 17 March 2020

11. FAO (2020) Land \& Water. http://www.fao.org/land-water/databases-and-software/cropinformation/en/ Accessed 17 March 2020

12. GEOFABRIK downloads (2018) OpenStreetMap Data Extracts. http://download.geofabrik.de/asia/lebanon.html Accessed 10 March 2020

13. Haydar Ch, Nehme N, Awad S, Koubayssi B, Fakih M, Yaacoub A et al (2014) Physiochemical and microbial assessment of water quality in the Upper Litani River basin. J Environ Earth Sci 4(9):87-97

14. Houri, A, El Jeblawi, SW (2007) Water quality assessment of Lebanese coastal rivers during dry season and pollution load into the Mediterranean Sea. J Water Health 5(4):616-623. https://doi.org/10.2166/wh.2007.047

15. Karam F, Abdul Halim M, El-Ali F, Mordovanaki G, Rouphael Y (2013) Wastewater management and reuse in Lebanon. J Appl Sci Res 9(4):2868-2879

16. Kumar P, Dasgupta R, Ramaiah M, Avtar R, Johnson BA, Mishra BK (2019). Hydrological simulation for predicting the future quality of Adyar River, Chennai, India. Int. J. Environ. Res. Public Health 16(23):4597. https://doi.org/10.3390/ijerph16234597

17. Kumar P, Masago Y, Mishra BK, Jalilov S, Rafiei Emam A, Kefı M, Fukushi K (2017) Current assessment and future outlook for water resources considering climate change and a population burst: A Case Study of Ciliwung River, Jakarta City, Indonesia. Water 9(6):410. https://doi.org/10.3390/w9060410

18. Lebanese Republic (2018). Statistical data-Population density according to the administrative structure. http://www.geo-ref.net/ph/lbn.htm Accessed 20 March 2020

19. Leong WK, Lai SH (2017) Application of water evaluation and planning model for integrated water resources management: case study for Langat River basin, Malaysia. Mater. Sci. Eng 210:012024. https://doi.org/10.1088/1757-899X/210/1/012024 
20. Ludwig F, Slobbe E, Cofino W (2014) Integrated water resources management and climate: change adaptation strategies. J Hydrol, Part B 518:235-242. https://doi.org/10.1016/j.jhydrol.2013.08.010

21. Majedi H, Fathian H, Nikbakht-Shahbazi A, Zohrabi N, Hassani F (2021) Multi-Objective Optimization of Integrated Surface and Groundwater Resources Under the Clean Development Mechanism. Water Resour Manage 35: 2685-270. https://doi.org/10.1007/s11269-021-02860-0

22. MoE, ELARD (2013) Lebanon - Environmental Pollution Abatement Project : environmental assessment: Environmental and social assessment (English) ) (Vol. 2, Report No. E4302). World Bank Group, Washington, D.C.

23. MoE, UNDP (2016) National guidelines for greenhouse rainwater harvesting systems in the agriculture sector. United Nations Development Programme, Beirut, Lebanon

24. MoE, EU, UNDP (2014) Lebanon environmental assessment of the Syrian conflict \& priority interventions. United Nations Development Programme, Beirut, Lebanon

25. MoE, UNDP, ECODIT (2011) State and Trends of the Lebanese Environment. United Nations Development Programme, Beirut, Lebanon

26. MoE, UNDP, GEF (2016) Lebanon's third national communication to the UNFCCC. Ministry of Environment, Beirut, Lebanon

27. MoEW, UNDP (2014) Assessment of groundwater resources of Lebanon. United Nations Development Programme, Beirut, Lebanon

28. Pallavi S, Yashas, SR, Anilkumar, KM, Shahmoradi B, Shivaraju HP (2021) Comprehensive Understanding of Urban WaterSupply Management: Towards SustainableWater-socio-economichealth-environment Nexus. Water Resour Manage 35:315-336. https://doi.org/10.1007/s11269-02002734-x

29. Quoc PB (2016) Assessment of Climate Change Impacts on Hydrological Processes and Water Resources by WEAP Model: Case Study in Phuoc Long Catchment. Dissertation, National Cheng Kung University

30. Ramadan HH, Beighley RE, Ramamurthy, AS (2012) Modelling streamflow trends for a watershed with limited data: case of the Litani basin, Lebanon. Hydrol Sci J 57(8):1516-1529. https://doi.org/10.1080/02626667.2012.727212

31. Ramadan HH, Beighley RE, Ramamurthy, AS (2013) Sensitivity analysis of climate change impact on the hydrology of the Litani basin in Lebanon. Int J Environ Pollut 52(1-2):65-81. https://doi.org/10.1504/IJEP.2013.056359

32. Rauf AU, Ghumman, AR (2018) Impact assessment of rainfall-runoff simulations on the flow duration curve of the Upper Indus River - a comparison of data-driven and hydrologic models. Water 16(7):876. https://doi.org/10.3390/w10070876

33. Salman M, Abukhalaf M, Del Lungo A (2016) Assessment of Treated Wastewater for Agriculture in Lebanon. Food and Agriculture Organization of the United Nations (FAO), Lebanon

34. Schuler PD (2012) Hydrological balance of the Jeita Spring catchment. Dissertation, University of Jordan 
35. Schuler PD, Margane A (2013) Water Balance of the Groundwater Contribution Zone of the Jeita Spring using WEAP, Including Water Resources Management Options \& Scenarios. (Project No.: 2008.2162.9, Protection of Jeita Spring, Technical Report No. 6). Council for Development and Reconstruction (CDR), Lebanon, Federal Institute for Geosciences and Natural Resources (BGR), Germany

36. SEI (2016) Water Evaluation and Planning System Tutorial: A collection of stand-alone modules to aid in learning the WEAP software. Stockholm Environment Institute, Boston, USA

37. Shaban A (2019) Striking Challenges on Water Resources of Lebanon. In: Javaid MS (ed) HydrologyThe Science of Water. IntechOpen, London. https://doi.org/10.5772/intechopen.81878

38. Shaban A (2021) Rivers in Lebanon: Significant Water Resources under Threats. In: Hromadka II ThV, Rao P (ed), Hydrology. London, UK: IntechOpen, London. https://doi.org/10.5772/intechopen.94152

39. Shaban A, Houhou R (2015) Drought or humidity oscillations? The case of coastal zone of Lebanon. J. Hydrol, Part 3 529:1768-1775. https://doi.org/10.1016/j.jhydrol.2015.08.010

40. Sieber J, Purkey D (2015) Water evaluation and planning system user guide. Stockholm Environment Institute, U.S. Center 11 Curtis Avenue Somerville, MA 02144 USA

41. Sjerps RMA, ter Laak TL, Zwolsman G.J.J.G (2017) Projected impact of climate change and chemical emissions on the water quality of the European rivers Rhine and Meuse: a drinking water perspective. Sci Total Environ 601-602:1682-1694. https://doi.org/10.1016/j.scitotenv.2017.05.250

42. Steveninck E, Arrieta L, Lloyd G, Thevenon F, Ashipala J, Gallo I, Fenni Y (2018) Climate change adaptation and integrated water resources management. UNDP. https://doi.org/10.13140/RG.2.2.29264.66560

43. Talib A, Randhir TO (2017) Climate change and land use impacts on hydrologic processes of watershed systems. J Water Clim Chang 8(3):363-374. https://doi.org/10.2166/wcc.2017.064

44. Trenberth, KE (2014) Water cycles and climate change. In: Freedman B (ed) Global Environmental Change: Handbook of Global Environmental Pollution, 1st edn. Springer, Dordrecht, pp 31-37

45. UNDP (2013) Energy from Wastewater Sewage Sludge in Lebanon 'Transforming a Waste Disposal Problem into an Opportunity'. Ministry of Environment, Beirut, Lebanon

46. Upadhyaya A (2016) Climate change adaptation and integrated water resource management in the water sector. Irrig Drain Syst 5(3):176. https://doi.org/10.4172/2168-9768.1000176

47. Verner D, Ashwill M, Christensen J, Mcdonnell R, Redwood J, Jomaa I et al (2018) Droughts and agriculture in Lebanon: causes, consequences, and risk management. World Bank Group, Washington, D.C.

48. Walnycki A, Husseiki M (2017) Five fundamentals to keep Lebanon's water flowing. International Institute for Environment and Development. https://www.iied.org/five-fundamentals-keep-lebanonwater-flowing Accessed 6 April 2020

49. Wasimi SA (2010) Climate change in the Middle East and North Africa (MENA) region and implications for water resources project planning and management. Int J Clim Chang Strateg Mana 2(3):297-320. https://doi.org/10.1108/17568691011063060 
50. World Bank (2016) Lebanon-Lake Qaraoun pollution prevention project (English) (Vol. 1, Report No. PAD860). World Bank Group, Washington, D.C.

51. World Weather Online (2020) Qartaba Monthly Climate Averages.

https://www.worldweatheronline.com/qartaba-weather-averages/mont-liban/lb.aspx Accessed 10 March 2020

52. Yaykiran S, Cuceloglu G, Ekdal A (2019). Estimation of water budget components of the Sakarya River basin by using the WEAP-PGM model. Water 11(2):271. https://doi.org/10.3390/w11020271

Figures

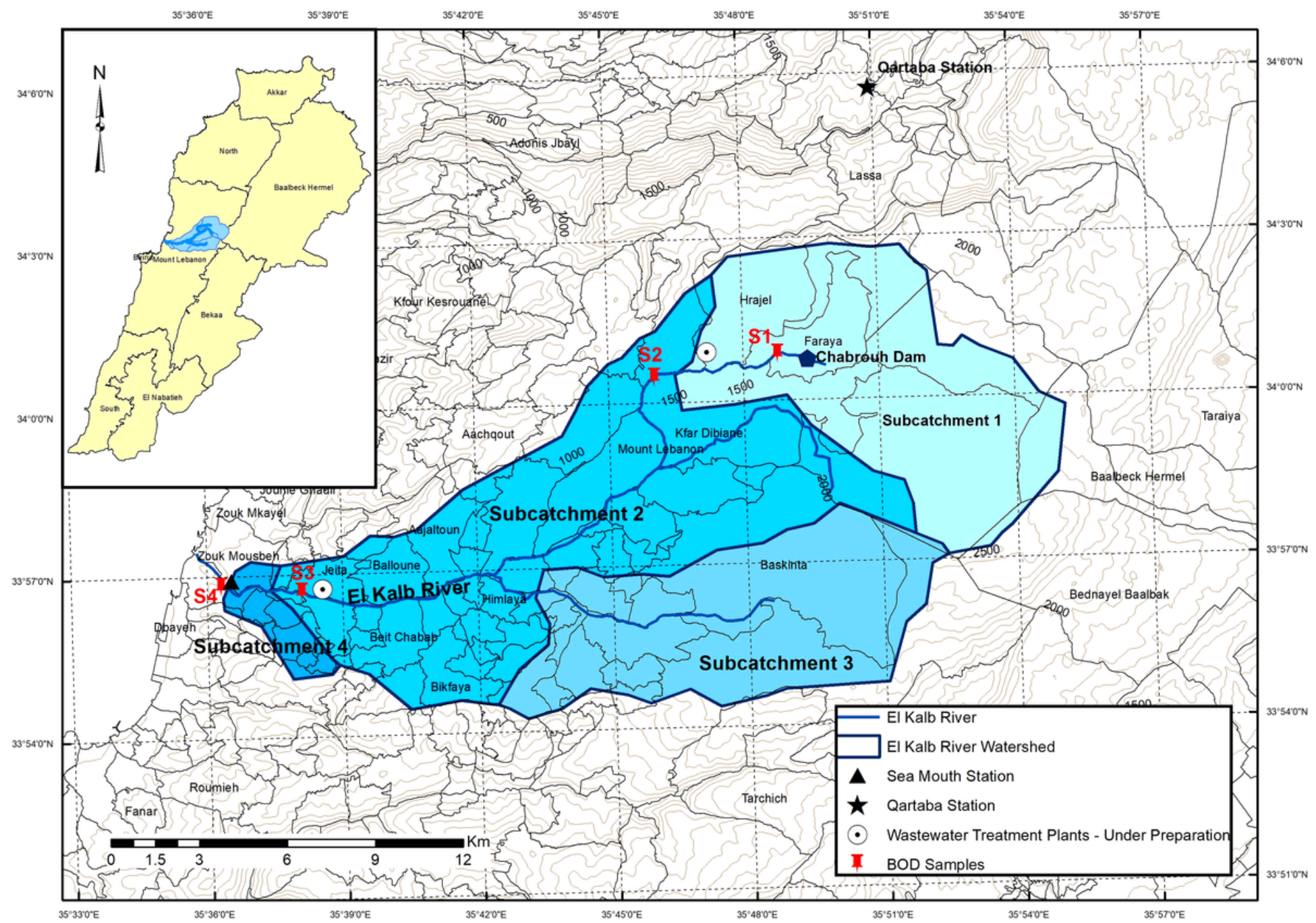

Figure 1

Map of El Kalb River catchment 

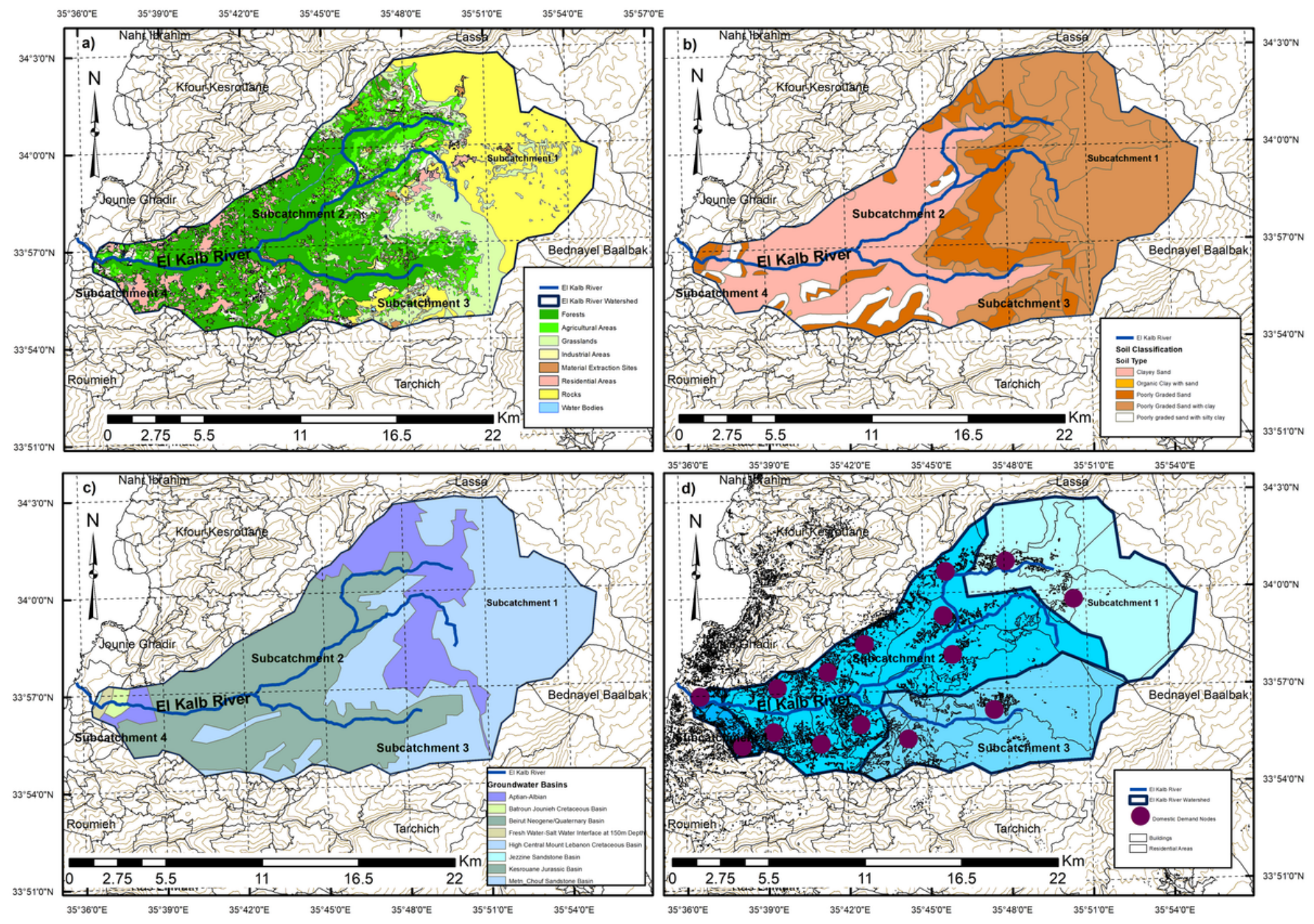

Figure 2

(a) Land use (b) Soil type (c) Hydrogeology (d) Domestic water demand sites 


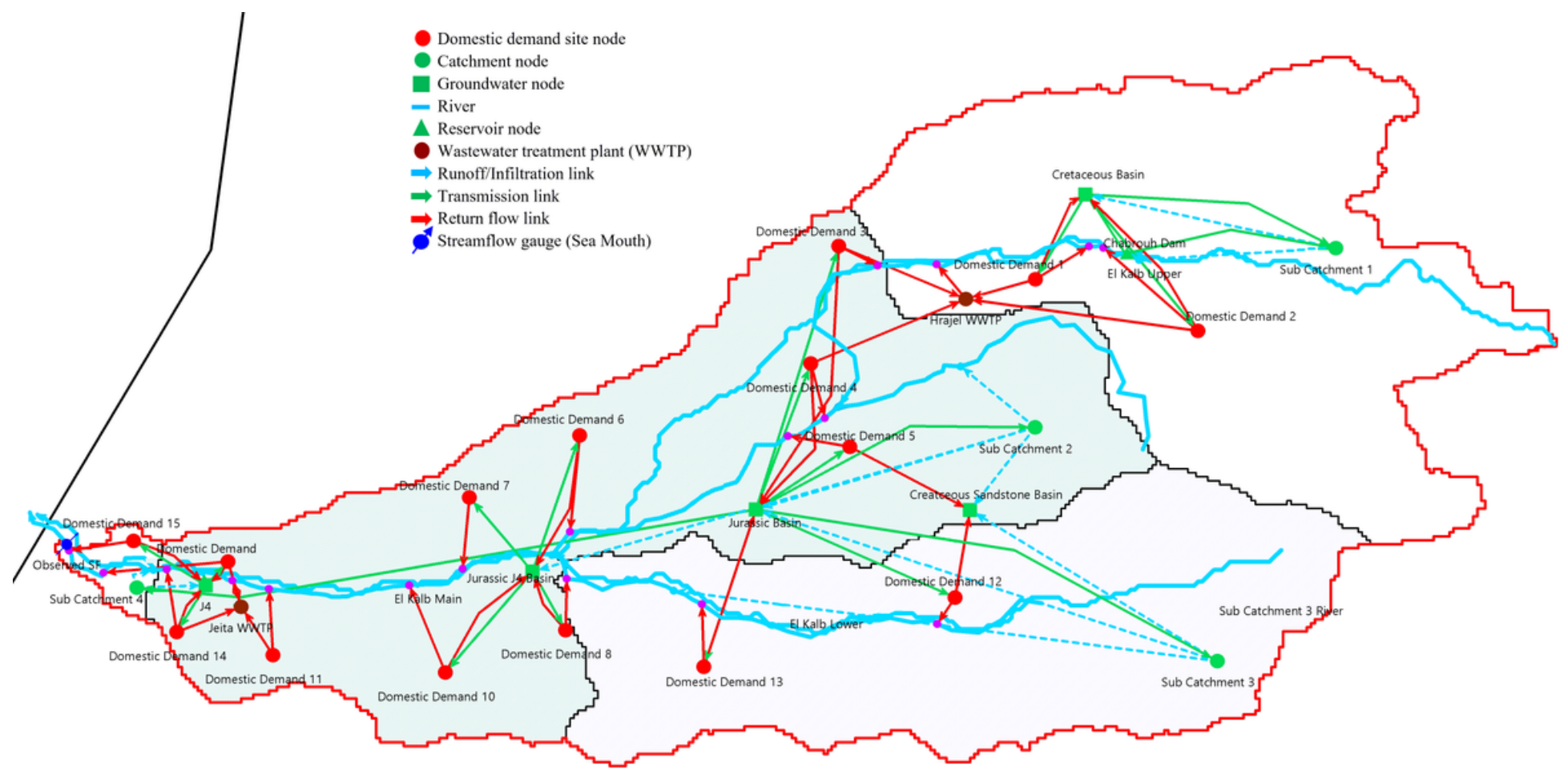

Figure 3

Configuration of the hydrological and water quality model components

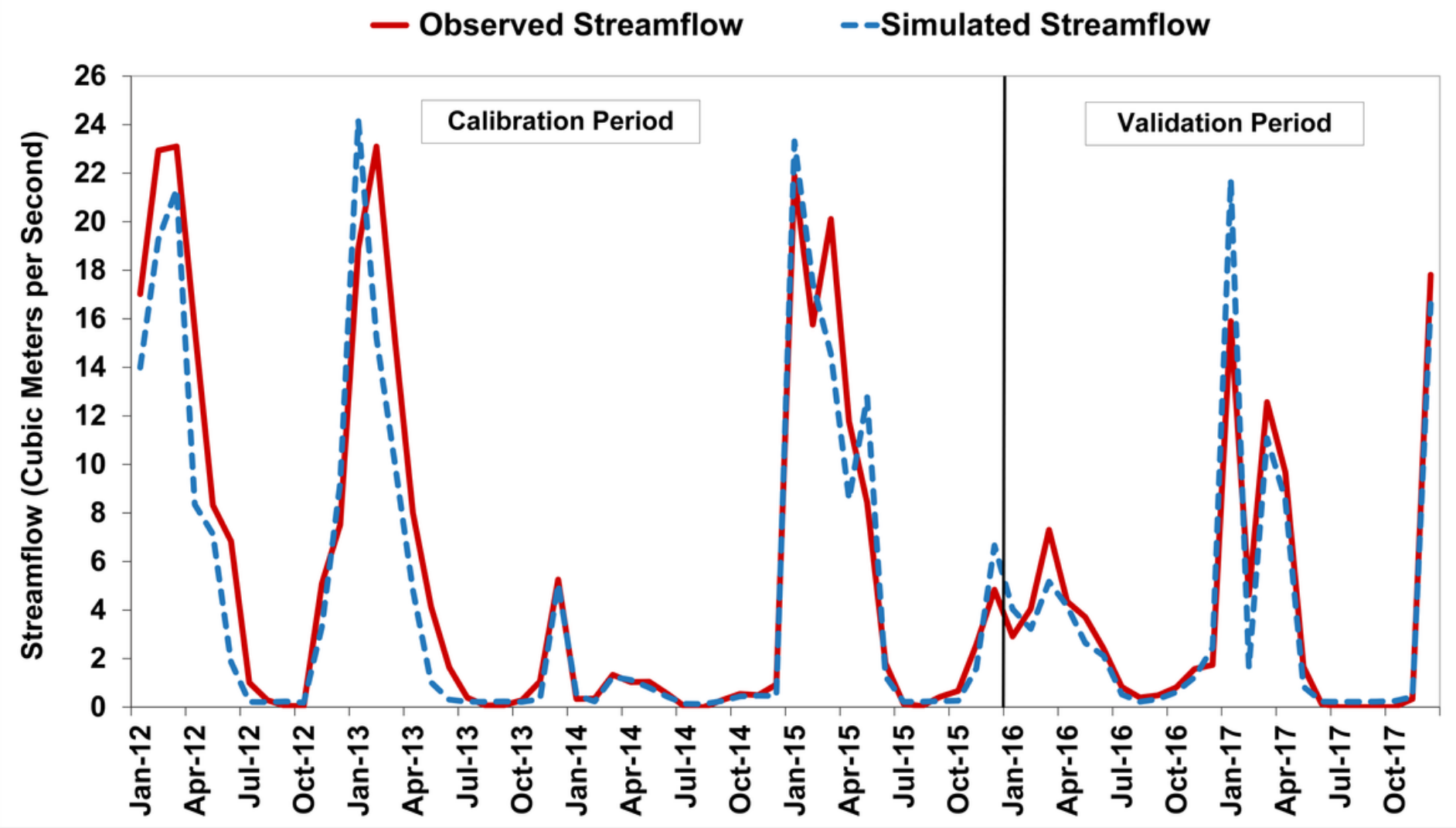

Figure 4 


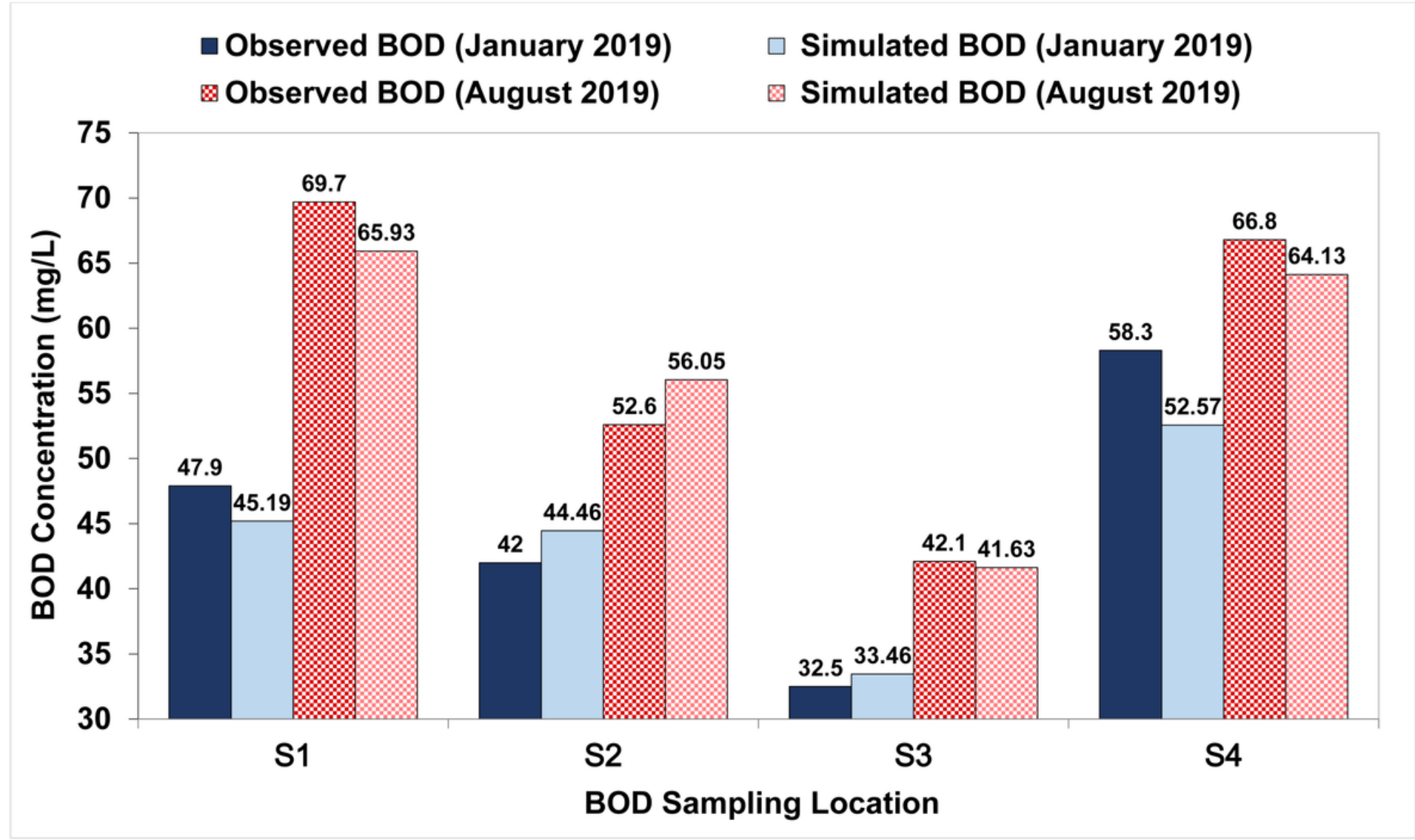

Figure 5

Observed and simulated BOD concentrations

Figure 6

(a) Maximum annual BOD concentration in El Kalb River at Sea Mouth point: (a) under Scenarios 1 and 3;

(b) under Scenarios 2 and 4

\section{Supplementary Files}

This is a list of supplementary files associated with this preprint. Click to download.

- SupportingInfomation.docx 